\title{
LAND RESTITUTION THROUGH THE LENS OF ENVIRONMENTAL LAW: SOME COMMENTS ON THE SOUTH AFRICAN VISTA
}

A du Plessis ${ }^{*}$

\section{Introduction: The marriage of the land restitution process with environmental law}

An efficient legal system is required to amend and adapt to changing needs and priorities. ${ }^{1}$ South Africa's political history of apartheid impacted on society (particularly peoples' rights in land), the economy and also, the environment. ${ }^{2}$ To many, the true test of the current national priorities of political transformation and development depends on whether land needs (including protection of and care for the environment) will be addressed effectively and in a sustainable way. ${ }^{3}$ In this, the South African legal system plays a substantial role. ${ }^{4}$ Hence sections 24 and 25(5), 25(7), 25(8) of the Constitution of South Africa, 1996

* Faculty of Law, North-West University, Potchefstroom Campus.

$1 \quad$ Badenhorst et al Silberberg and Schoeman's The Law of Property 481.

2 Until 1991, the prominent characteristic of the South African land control system was that it was racially based. Although the process of racial segregation of land control had already begun under the colonial authorities, it gained particular momentum with the commencement of the so-called "Land Acts" of 1913. It is estimated that about 17000 statutory measures had been issued until 1991 in order to regulate land control in relation to racial diversity. See for explanatory discussions and historical overviews, Mostert 2002 The South African Law Journal 400, Badenhorst et al Silberberg and Schoeman's The Law of Property 481, Du Plessis, Olivier and Pienaar 2004 SA Public Law 456 and De Villiers 2000 (4) SA Public Law 427.

3 De Villiers 2000 (4) SA Public Law 426 proposes that "no doubt exists that the democratic transition in South Africa will in the final analysis be measured against its ability to cater for social and economic demands - and in particular access to land - of its citizens". The White Paper on South Africa's Land Policy of 1997 furthermore describes the current, post-1994 land policy as "a cornerstone in the development of our country".

4 It is, for example, suggested by Van der Walt 1997 SA Public Law 275-330 that a socially responsible and thus fundamentally limited notion of land ownership is more appropriate in the current constitutional context. He explains that a just and equitable balance has to be struck between the protection of existing individual property rights such as ownership and the public interest in land reform and the transformation of the existing property regime. 
(hereafter the Constitution) and related legislation may be of key importance for sustainable development ${ }^{5}$ and democratic change. ${ }^{6}$

Section 24 states that:

Everyone has the right-

(a) to an environment that is not harmful to their health or well-being; and

(b) to have the environment protected, for the benefit of present and future generations through reasonable legislative and other measures that-

(i) prevent pollution and ecological degradation

(ii) promote conservation; and

(iii) secure ecologically sustainable development and use of natural resources while promoting justifiable economic and social development.

Sections 25(5), 25(7) and 25(8) of the Constitutional property clause address some of the components of land reform and determine that:

(5) The state must take reasonable legislative and other measures, within its available resources, to foster conditions that enable citizens to gain access to land on an equitable basis.

(7) A person or community dispossessed of property after 19 June 1913 as a result of past racially discriminatory laws or practices is entitled, to the extent provided by an Act of Parliament, either to restitution of that property or to equitable redress.

5 S 24(b)(iii) explicitly refers to "sustainable development". For the purpose of this paper, sustainable development will be afforded the meaning derived from the UN General Assembly Our Common Future. The Report defines sustainable development as “... development that meets the need of the present generation without compromising the ability of future generations to meet their own needs". See for application and analyses of this concept Bray 1998 SAJELP 2; Scholtz 2005 Journal of South African Law 69.

6 Mostert 2002 The South African Law Journal 404 indicates that "law by itself cannot bring about development or effect social justice and security, but laws can facilitate societal change. Hence, the law is a valuable instrument in managing development, but political, economical, socio-cultural and environmental factors will shape the development process". 
(8) No provision of this section may impede the state from taking legislative and other measures to achieve land, water and related reform, in order to redress the results of past racial discrimination, provided that any departure from provisions of this section is in accordance with section 36(1).

Land reform in terms of section 25 may strongly impact on the environment and sustainable development as protected in section 24 since it involves vast hectares of land, other environmental media and people. The restitution of land, the focus point of this article, is one of the legs of land reform in South Africa. ${ }^{7}$ Land restitution is regulated, inter alia, by section 25(7) of the Constitution, the White Paper on South Africa's Land Policy of $1997^{8}$ (hereafter the White Paper) and the Restitution of Land Rights Act 22 of 1994 (hereafter the RLRA). Section 24 of the Constitution, the Environmental Conservation Act 73 of 1989 (hereafter the ECA) and the National Environmental Management Act 107 of 1998 (hereafter the NEMA), on the other hand, are some environmental law instruments that aim at protection of the environment, the prevention of pollution, the promotion of conservation and secured ecologically sustainable development by means of, inter alia, co-operative and environmental governance. $^{9}$

After ten years of democratic rule, South Africa has reached a critical moment in respect of land restitution. ${ }^{10}$ Some of the reasons for this include that the

7 Land restitution aims at compensating people who were removed from their land as part of the consolidation of homelands or the so-called "black spot" removal programme of the past. Land restitution is a claim-driven process that requires basic evidence that people were deprived of their ancestral land in a manner that would be unconstitutional after 1996. See in this regard Mostert 2002 The South African Law Journal 406; De Villiers Land Reform: Issues and Challenges 51. See for an analysis of recent public concerns with regard to restitution of land raised in the press, Du Plessis, Olivier and Pienaar 2005 SA Public Law.

$8 \quad$ White Paper on South African Land Policy Department of Land Affairs April 1997.

9 Co-operative governance in terms of ch 3 of the Constitution requires of all spheres of government and all organs of state within each sphere to conduct their tasks in a manner that is conducive to national unity and the attainment of national goals. Environmental governance is defined in par 2 below.

10 For a recent critical perspective on land reform in South Africa, see the Centre for Development and Enterprise's Research Report entitled Land Reform in South Africa: A $21^{\text {st }}$ Century Perspective, CDE Research Report http://www.cde.org.za/pdf/LandReform.pdf 
initial targets for land restitution as envisaged by the White Paper, in retrospect shown to have been unfeasible and unrealistic; ${ }^{11}$ that by December 2004 , according to the DLA Performance Review, 57257 claims (about seventy percent of some 80000 submitted by the 1998 deadline) had been settled and 812315 hectares of land had been transferred; and that by the end of 2004 , there were 22437 claims yet to be settled. Of these, 13237 are urban while 9 200 are rural. $^{12}$ The latter claims are very complex and tend to involve more people. ${ }^{13} \mathrm{~A}$ recent research report of the Centre for Development and Enterprise's Research, sponsored by the United Kingdom, furthermore indicates that

...the development outcomes of many rural restitution projects have been less than satisfactory. ${ }^{14}$

In February 2005, the target date for settling all restitution claims was also moved from the end of 2005 to the end of the 2007/8 financial year, whilst in February 2005, the government determined its restitution budget on R9.9 billion for the three years up to $2007 / 8 .^{15}$ In addition to the almost "statistical" reasons offered for land restitution to be a critical national issue, communities and

14 Apr. See for a discussion of some key land restitution issues, Mbao 2002 Journal for Juridical Science 91-92.

11 In terms of the White Paper of 1997 all claims would be lodged within a three-year period, the Commission on the Restitution of Land Rights would finalise all claims within a period of five years and all court orders of the Land Claims Court would be implemented within a period of ten years. See Badenhorst et al Silberberg and Schoeman's The Law of Property 511.

12 DLA http://land.pwv.gov.za/ 13 Apr.

13 These claims are more difficult to resolve and as a result, the settlement of rural claims has progressed more slowly.

14 CDE Research Report 2005 6. Mostert 2002 The South African Law Journal 427 also indicates that "the poverty pervading many of the communities involved in restitution claims - even after successful completion of the claims - is still shocking" and that "successful claimants' dispossession of the skills needed for using the restored land effectively, is almost never considered in settlements". Mbao 2002 Journal for Juridical Science 111-112 lists some of the challenges with regard to law and administration in the land restitution delivery process. These include, amongst others: lack of synergy between the restitution process and socio-economic development needs of successful claimants, including problems resulting from poor co-ordination between the various governmental agencies involved with issues of reconstruction and development at national and provincial levels; organisational constraints within the Commission for the Restitution of Land Rights; organisational constraints within associated government departments and weak organisation of rural communities.

15 National Treasury, Vote 29: Land Affairs National Estimates of Expenditure 200527 at Transformation Audit http://www.transformationaudit.org.za/ 13 Apr. 
individuals who lodged land claims are adamant and impatient. Farmers or owners currently residing on claimed land are generally dissatisfied with compensation offered by government and the Land Claims Court (hereafter the LCC) and its adjudicating processes are critically scrutinized in public. ${ }^{16}$ Hence the compelling pressure on government, especially the Department of Land Affairs (hereafter the DLA) to speed up restitution. ${ }^{17}$

Acceleration of the land restitution process may be at the cost of environmental sustainability, ${ }^{18}$ effective co-operative and environmental governance and in disregard of the possible risk that restitution processes persist without due regard to environmental rights protected by section 24. In support of Glazewski's viewpoint that "the link between property rights and environmental concerns is fundamental", it is argued in this article that both sections 24 and 25 of the Constitution are cardinal for development in South Africa. ${ }^{19}$ In correlation with the wording of both sections, "reasonable legislative and other measures" should be developed in order to realise the constitutional protection afforded. ${ }^{20}$ In order to achieve development and the realisation of both sections 24 and 25(7), co-operative and environmental governance and support, the clarification of the roles of government, the integrated application of land restitution and environmental policy as well as utilization of environmental

16 For an analysis of recent concerns of the public with regard to restitution raised in the press, see Du Plessis, Olivier and Pienaar 2005 SA Public Law. See also De Villiers 2000 (4) SA Public Law 32. Regard should however be given to the view held in the CDE Research Report http://www.cde.org.za/pdf/LandReform.pdf that government has not been emphatic enough in communicating the successes that have been achieved thus far in land reform. The report indicates that officials do not adequately brief journalists, with the result that the latter often fail to recognise or acknowledge the real progress that has been made in an extremely difficult arena.

17 See also the CDE Research Report http://www.cde.org.za/pdf/LandReform.pdf.

18 Sustainability for the purpose of this paper is defined as: "The ability to maintain a desired condition over time without eroding natural, social and financial resource bases, through a process of continual improvement in the form of sustainable development. Sustainability furthermore relates to the integration of various considerations, including: the environment, the economy, social factors, environmental governance and management efforts, and public industry involvement." Adapted from Bosman Waste Disposal or Discharge 8-12. Sustainability is regarded as one of the major goals of development in South Africa. One indication that development may be sustainable is when communities or people regard development as having brought lasting and meaningful change to their lives. See in this regard, Scheepers Practical Guide 21.

19 Glazewski Environmental Law 82.

20 S 24(b) and 25(5). 
principles and the determination of impacts on the environment, may be of key importance.

The questions posed in this article are whether co-operative and environmental governance are provided for in the existing land restitution program, whether the application of land restitution and environmental policies is integrated as required by the Constitution, whether the phases of land restitution provide for environmental matters, and in a culminating sense, whether or not the increasingly rapid implementation of section 25(7) could impede some of the objectives of section 24. In order to limit the scope of the article, a critical overview is provided of the legal framework on environmental governance in South Africa, the national legal framework for land restitution and some environmental initiatives that might relate to land restitution. For a more practical understanding of some of the issues raised in this article, brief reference is made of a land restitution case. The article concludes with some comments and suggestions for the way forward.

\section{The legal framework on environmental governance in South Africa}

The term "environmental governance" has a multi-thematic nature, and is defined for the purpose of this paper as:

The collection of legislative, executive and administrative functions, processes and instruments used by any organ of state to ensure sustainable behaviour by all as far as governance of environmental activities, products services, processes and tools are concerned. ${ }^{21}$

Environmental governance is an explicit mandate of government in terms of section 24 and the NEMA. Since government in essence drives land restitution, and since it is an activity that may potentially impact on the environment, environmental governance may not be disregarded in the process of realising 
section $25(7) .{ }^{22}$ Co-operative governance, in terms of section $41(1)$ of the Constitution requires of all spheres of government to exercise their powers and perform their functions in a manner that does not encroach on the geographical, functional or institutional integrity of government in another sphere. Considered inclusion of environmental and co-operative governance in different phases of land restitution, arguably enables the joint realisation of sections 24 and 25(7) in a supportive manner and without sacrificing any of the core elements contained in these two distinct rights. Environmental and cooperative governance may provide the keys to "sustainable restitution of land" restitution of land that does not contravene or hinder the spirit of, and rights of, present and future generations protected in section 24.

National legislation that enables and regulates land restitution should arguably provide for environmental and co-operative governance in each step of the initial process as well as in post-settlement support endeavours. In order to determine the status quo of provision for environmental matters in land restitution law in paragraph 3 , the subsequent sections briefly reflect on the legal framework for environmental governance currently in existence in South Africa. $^{23}$

\subsection{The Constitution of South Africa, 1996 - Section 24}

The Constitution is regarded as an imperative component of the legal system of the country and the legal-institutional framework within which development has to take place. ${ }^{24}$ The rights contained in the Bill of Rights unmistakably relevant

22 For the purpose of this paper, the NEMA s 1 definition of "environment" should be kept in mind. "Environment" is defined in s 1 of the NEMA to mean: "The surroundings within which humans exit and that are made up of -land, water and atmosphere of the earth; micro-organisms, plant and animal life; any part or combination of (i) and (ii) and the interrelationships among and between them; and the physical, chemical, aesthetic and cultural properties and conditions of the foregoing that influence human health and wellbeing."

23 The aim is to distil some of the environmental law provisions that may require compliance by government in land restitution practices.

24 Scheepers Practical Guide 36. Administration and management of development and projects and programmes aimed to achieve development, must for example conform to the 
for development include, amongst others, the right related to the environment (section 24), the right to property (section 25) and the right to just administrative action (section 33). ${ }^{25}$ These rights may be limited only by way of a law of general application and in the manner provided for in the section 36 limitation clause.

Section 24 of the Constitution imitates the pattern of the Bill of Rights that in its entirety includes both traditional fundamental rights (particularly the equality clause, the right to dignity and the right to life) and socio-economic rights such as the right to housing and social security. ${ }^{26}$ This characteristic relates to section 24 being regarded as anthropocentric in nature focusing together with the NEMA, on people and their needs and interests. It furthermore focuses on development that must be socially, environmentally and economically sustainable. $^{27}$

Section 24(a) contains a justiciable right and states that "everyone shall have the right" to a healthy environment, indicating that individuals as well as groups of people are bearers of this right. The conduct of the state or a private individual or institution violating this right may accordingly be challenged. Section 24(b), on the other hand, imposes a positive duty on the state to take steps to protect the environment. According to Badenhorst et al, this subsection grants individuals an extended justiciable right in that the state can also not employ measures which could be considered retrogressive in relation to the

democratic values and principles governing public administration stated in s 195 of the Constitution.

25 Scheepers Practical Guide 38. Ch 3 and s 195 of the Constitution which deal with cooperate government and the basic values that govern public administration may be of less obvious, however key relevance for development in general. S 195 determines that public administration must be governed by the democratic values and principles enshrined in the Constitution. S 195(1)(a) to 195(1)(i) list these principles. S 195(2) states that the listed principles apply to administration in every sphere of government, organs of state and public enterprises.

26 Note that several rights protected in the Constitution may pertain to the environment and environmental protection. These include, eg the right to administrative justice (S 33) and the right to access to information (S 32). These will, however, for the purpose of this article, not be discussed. See further Glazewski Environmental Law 65-102.

27 Scholtz 2005 Journal of South African Law 69. For a critical discussion of an anthropocentric approach to environmental management, see Scholtz 2005 Journal of South African Law 70-75. 
protection of the environment, or which actively harm the environment. ${ }^{28}$ The objectives of section 24(b) are to be achieved for present and future generations through reasonable legislative and other measures. ${ }^{29}$ Should the state accordingly not take the necessary measures to secure the goals of, inter alia, securing ecologically sustainable development and the use of natural resources while promoting justifiable economic and social development, the individual right to have the environment protected will be violated. ${ }^{30}$

The section 24(b) "legislative and other measures" may also be expected to ensure environmental governance practices that are aimed at the achievement of sustainable results. Section 24(b) therefore arguably also applies to legislation on non-environmental, but environmental impacting activities and other measures instituted for the realisation of different constitutional rights. These may include the different property rights protected in section 25. All government action and legislation (including the land restitution process and land restitution law) as well as individual conduct (for example the behaviour or actions of land restitution beneficiaries) that impacts on the environment, must be in compliance with section 24 unless a limitation is allowed in terms of section 36 .

The qualification that ecologically sustainable development is to be pursued "while promoting justifiable economic and social development", in section 24(b)(iii), must be seen in the context of the inclusion of socio-economic rights in the Bill of Rights as a whole. This raises the concern that in government's strive to fulfil its obligations in terms of social developmental rights, such as the property rights protected in section 25 , it may trump other legal claims, including section 24 environmental concerns. Seen in the light of pressing land needs and government's haste in finalising land claims, such "trumping" of section 24 in favour of land restitution in terms of section $25(7)$ is not unlikely. ${ }^{31}$

28 Badenhorst et al Silberberg and Schoeman's The Law of Property 403.

29 Glazewski Environmental Law 84-86.

30 Badenhorst et al Silberberg and Schoeman's The Law of Property 406.

31 See in this regard the court's ruling in Minister of Public Works $v$ Kyalami Ridge Environmental Association 2001 (7) BCLR 652 (CC). In this case government sought to 
However, it may in practice bring about an irreversible contravention of the environmental rights of current and future generations as protected by the Constitution.

\subsection{The National Environmental Management Act 107 of 1998}

The NEMA is regarded as framework legislation that embraces resource conservation and exploitation, pollution control and waste management as well as land-use planning and development (chapter 1 of the NEMA). The NEMA is underpinned by the notion of "sustainable development" being defined in the Act as the "integration of social, economic and environmental factors into planning, implementation, and decision-making so as to ensure that development serves present and future generations". The concept of sustainable development has been concretised in a set of detailed and complex environmental principles at the base of the NEMA. ${ }^{32}$ The 18 environmental principles cover a wide spectrum of aspects set out in chapter 1 of the NEMA and

...apply throughout the Republic to the actions of all organs of state that may significantly affect the environment. ${ }^{33}$

Some of the principles are peculiar to developing South Africa, for example section 2(4)(d) that determines that

establish a transit camp for people rendered homeless as a result of severe floods and the question arose around the balancing of the right to housing in terms of $s 26$ of the Constitution and environmental concerns. Taking into account the compelling need of the homeless people on the evidence placed before the court, the court found that in effect, the government's duty to fulfil its obligations in terms of the right to housing could be regarded as more important than other legal claims, including the environmental concerns of the respondents in the case. See also a discussion of environmental conservation and the concept of ownership as an absolute and unrestricted right based on the former ruling, Freedman 2001 SAJELP 128-134.

32 Cheadle, Davis and Haysom South African Constitutional Law 424 and Glazewski Environmental Law 138.

33 Glazewski Environmental Law 141 suggests that the principles are applicable not only to organs of state but also to private juristic persons in the same way that the environmental right has horizontal application. 
...equitable access to environmental resources, benefits and services to meet basic human needs and ensure human well-being must be pursued and special measures may be taken to ensure access thereto by categories of persons disadvantaged by unfair discrimination. ${ }^{34}$

Chapter 3 of the NEMA is entitled "Procedures for Co-operative Governance" and provides for stipulated national government departments and the nine provinces of the country to prepare environmental management plans and/or environmental implementation plans. ${ }^{35}$ The essence of environmental implementation and environmental management plans includes the giving of effect to the principle of co-operative governance and preference afforded to national rather than provincial interests where the latter are unreasonable or prejudicial to the interests of the country as a whole. ${ }^{36}$ Note that since the DLA is included in both Schedules 1 and 2 of the NEMA, it may be legally expected of this department to prepare, and act according to both of the said plans.

\subsection{The Environment Conservation Act 73 of 1989}

Central to the ECA is Part 5 that regulates the control of activities that may have a detrimental effect on the environment. The Act adopts "a two-pronged approach" by empowering the Minister of the Department of Environmental Affairs and Tourism (hereafter DEAT), to declare either "activities" or "limited development areas" with certain environmental assessment consequences (sections 21 and 23 of the ECA). Where activities have been declared, no such activity may be undertaken unless written authorisation has been obtained from

34 Some of these principles are discussed below. Note that the environmental principles apply alongside other relevant considerations such as the State's responsibility to respect, promote and fulfil socio-economic rights such as the Section 25 property rights in the Constitution. Glazewski Environmental Law 138 indicates that in applying the principles, decision-makers are not only to consider ecological factors but also social considerations. It is however suggested that when it comes to the restitution of land as essentially a social issue, environmental factors and principles should also be considered. The set of comprehensive environmental management principles is preceded by the general provision that development must be socially, environmentally and economically sustainable (s 2(3) of the NEMA).

$35 \mathrm{~S} 11$ of the NEMA.

36 See in this regard Glazewski Environmental Law 146. 
the Minister or the Premier of the Province. The relevant authority may require reports on the impact of the proposed activity and of alternative proposed activities on the environment (section 22(2)). Regulation 1182 of 1997 lists 11 activities for which an EIA (environmental impact assessment) has to be submitted in terms of section 21 of the ECA. In 2002 the schedule was amended to make some additions and refinements. ${ }^{37}$ Some of the current listed activities that may be applicable in land restitution or post-settlement processes include: the construction, erection or upgrading of roads, structures associated with communication networks, reservoirs for public water supply, public and private resorts and associated infrastructure and the change of land use from agricultural or zoned undetermined use to any other land use, use for grazing to any other form of agricultural use and use for nature conservation or zoned open space to any other land use.

As indicated by the restitution case briefly referred to below, in accelerating land restitution endeavours and in addressing more pressing challenges, the environmental impacts and the assessment thereof seems not to be a priority of government. Taking these findings into account as well as the escalating numbers of land claims that are "finalised", ${ }^{38}$ the conducting of EIA's and the obtaining of environmental authorisation in most land restitution cases are questioned. This is an alarming state of affairs since an EIA may in terms of law not be required retrospectively, but alternative remedies to the EIA provisions have to be sought in seeking redress. ${ }^{39}$ Section $24 \mathrm{G}$ of the National Environmental Management Amendment Act 8 of 2004 however recently replaced section 24 of the Act and now makes provision for retrospective authorisation. To promote compliance with the environmental regulations in terms of the ECA, individuals and companies were offered a window-period opportunity to rectify any unlawful commencement or continuation of activities that degrade the environment and would require authorisation. Failure to

37 Glazewski Environmental Law 237.

38 See in this regard CRLR http://land.pwv.gov.za/restitution $13 \mathrm{Apr}$, the Report of the Office of the Chief Land Claims Commission, entitled "Land Restitution in South Africa: Our Achievements and Challenges", March 20034.

39 See the ruling in the Silvermine Valley Coalition v Sybrand van der Spuy Boerderye 2002 (1) SA 478 (CPD). See also the discussion in Glazewski Environmental Law 239. 
comply with environmental regulations constitutes a criminal offence. Individuals and companies could make use of the window period between 7 January 2005 and 7 July 2005 to apply for rectification in terms of these regulations and avoid prosecution with possible fines and or imprisonment. Glazewski indicates that the new regime may prove to ignore pressing development issues such as "poverty reduction and the socio-economic consequences of development" ${ }^{40}$ Land restitution in the name of development, and the people involved in the different phases thereof, may nevertheless not manage to escape the obligation to comply. The urban and rural beneficiaries of land claims, whether or not informed or capacitated with resources, may be expected to comply with obligations in terms of section 24G. However it is doubtful that many land claims beneficiaries in rural areas specifically have been informed about this window period and have applied for rectification where activities have proceeded since the enactment of the RLRA without the necessary environmental authorisation.

The corpus of framework environmental law in South Africa provides for environmental governance. Environmental governance in terms of amongst others, section 24 of the Constitution, the NEMA and the ECA falls within the cadre of the public administration as provided for and regulated by the Constitution. Government may therefore encounter difficulty in justifying its discounting of environmental governance in land restitution matters.

40 Glazewski Environmental Law 247-248 further indicates that the new regime "pivots around the notion" of an environmental authorisation which is provided for in s 24 as it states that "the potential impact on the environment of listed activities must be considered, investigated, assessed and reported to the competent authority". 


\section{The legislative and institutional framework for land restitution in South Africa}

Land reform in South Africa takes place within the broad framework of a human rights-based Constitution and in terms of a set of national land reform laws. ${ }^{41}$ The goal of the restitution programme (as one of the components of land reform) is to restore land and to provide for related remedies for those previously dispossessed by legislation and practice, in a way that supports the vital processes of reconciliation, reconstruction and development. ${ }^{42}$ This paper proposes that land restitution law and related government action have to make provision for environmental governance in order to contribute to the vital processes of reconciliation, reconstruction and development. The incorporation of key environmental principles in land restitution law and the pre-settlement determination of the feasibility of a land claim and development activities to follow a successful land claim, may be central to restoring a balance between the need for development and the need to protect the environment.

In order to explore the land restitution legal framework and to assess whether the former provide for environmental governance, the inclusion of environmental principles and environmental impact assessments in land restitution law as well as the integrated application of land restitution and environmental laws, a brief exposition of the Constitutional property right and existing land restitution law is provided in subsequent paragraphs.

41 Note that the Constitution of South Africa Act 200 of 1993 (the interim Constitution), introduced a new approach to land reform. See De Villiers 2000 (4) SA Public Law 429. However, for the purpose of this article, only the provisions contained in the 1996 Constitution will be discussed.

42 Adapted from the Reconstruction and Development Programme. See further Badenhorst et al Silberberg and Schoeman's The Law of Property 511. 


\subsection{The Constitution of South Africa, 1996 - Section 25}

According to the White Paper, section 25 was highly disputed in the Constitutional negotiations, and was one of the last issues to be resolved. The Constitution now seeks to achieve a balance between the protection of existing property rights on the one hand, and the constitutional guarantees of land reform on the other. The property clause provides clear constitutional authority for land reform - section 25 protects private property from confiscation by the state, and requires any expropriation of property to be compensated. Concurrently, the property clause requires of the State to actively pursue the goals of land redistribution and the reform of land tenure rights and to grant people an entitlement to the restitution of property of which they were dispossessed in pursuance of apartheid policies. ${ }^{43}$

Section 25(7) delineates the constitutional right to land restitution. This section grants a right to restitution "to the extent provided by an Act of Parliament" of property to persons and communities dispossessed of property as a result of discriminatory legislation after $1913 .{ }^{44}$ No obligation is imposed on the State to enact the legislation referred to in this sub-section, presumably because the RLRA was already enacted by the time the final Constitution came into effect. ${ }^{45}$

43 See in this regard De Waal, Currie and Erasmus The Bill of Rights 411.

44 The extent of the right to restitution of land, or to redress in the form of alternative land or compensation where restitution cannot be made, is set out in the RLRA. Note that the Act restricts the restitution entitlement to persons or communities dispossessed of "rights in land". Two further restrictions include that claims for restitution must have been lodged by 31 December 1998 and that the Act excludes claims for restitution if just and equitable compensation was paid for the dispossession. See also De Waal, Currie and Erasmus The Bill of Rights 428. For an exposition of the scope and application of the process of restitution as provided for in the Constitution as well as the test that is applied to determine whether dispossession was a result of past discriminatory actions, see De Villiers Land Reform: Issues and Challenges 52.

45 Cheadle, Davis and Haysom South African Constitutional Law 471. There would arguably be no reason for, or point in, repealing the RLRA since claims that were lodged by the statutory cut-off date have already vested, and could therefore not be repudiated. See Cheadle, Davis and Haysom South African Constitutional Law 205. It may be derived that the RLRA and the amendments thereto, comply with the core principles embedded in the Constitution. It should however be noted that $\mathrm{s}$ 7(2) of the Constitution states that the state must respect, protect, promote and fulfil the rights in the Bill of Rights whilst $s$ 8(1) states that the Bill of Rights applies to all law and binds the legislature, the executive, the judiciary and all organs of state. Hence, even where the set of land restitution law conforms to all Constitutional provisions, it is not to say that certain actions or a refrain 
One of the questions that the constitutional property clause may raise for environmental conservation is whether the Constitution prevents the imposition of restrictions on property rights for environmental purposes and, if not, whether such restrictions will result in compensation having to be paid to the holder of the rights in question. ${ }^{46}$ By keeping the aim of sustainable development in mind, this article aims to determine what may be expected of government in terms of section 24 when realising the right to property in terms of section 25(7). The question therefore is whether the current legal framework on land restitution ultimately enables the protection of the environment as provided for by section 24. Characteristic of the former may, inter alia, be co-operation between the DLA and the DEAT, the clarification of their respective roles and contributions and the inclusion of environmental principles and environmental impact assessments from the beginning to the end in the restitution process.

\subsection{The White Paper on Land Reform of 1997}

In terms of the White Paper, the purpose of land reform is to redress the injustices of apartheid, to foster national reconciliation and stability, to underpin economic growth, improve household welfare and to alleviate property. ${ }^{47}$ The White Paper explicitly recognises the environment since it is, inter alia, based on the idea that economic viability and environmental sustainability are of the utmost importance for its success. ${ }^{48}$ The White Paper recognises, amongst

from taking action, as part of the land restitution process may not be found unconstitutional. See in this regard Rautenbach and Malherbe Staatsreg 345.

46 Kidd Environmental Law 41.

47 White Paper on South African Land Policy April 1997. The government published the White Paper with the aim providing an overall plan for land reform dealing with restitution, restoration and tenure reform. Issues that impact on land policy were identified, such as market-driven reform, the statutory framework within which land reform has to occur, environmental issues, budgetary constraints and the three main elements of the policy. See also De Villiers Land Reform: Issues and Challenges 52.

48 Par 3.12 to 3.14. It is interesting to note that some of the issues that were raised as part of public response to the Green Paper on South Africa's Land Policy, included that the roles and responsibilities for land administration at the different levels of government should be clarified and that better coordination between different departments is required. Many of the written submissions by statutory organisations and national government departments 
other deficiencies, the lack of effective, integrated environmental management. It is however silent on clear provisions or strategies for the implementation and integration of environmental matters in, for example, the restitution of land process.

\subsection{The Development Facilitation Act 67 of 1995}

The Development Facilitation Act 67 of 1995 (hereafter the DFA) has been described by Glazewski as:

...the flagship statute passed by the new government which sets the overall framework and administrative structure for planning throughout the country. ${ }^{49}$

The basic aim of the DFA as administered by the DLA, is to introduce extraordinary measures to facilitate and speed up the implementation of reconstruction and development programmes and projects in relation to land and in so doing lay down general principles governing land development throughout South Africa. ${ }^{50}$ Its general principles for land development and conflict resolution do mention environmental considerations. It is, inter alia, provided that policy, administrative practice and laws should promote efficient and integrated land development in that they should for example encourage environmentally sustainable land development practices and processes (section 3(1)(c)(viii) of the DFA). The promotion of sustained protection of the environment is laid down as a factor to be taken into account in the promotion of sustainable land development (section $3(1)(h)(i i i)$ of the DFA). ${ }^{51}$

indicated that environmental issues (national and cultural) should be integrated in the White Paper.

49 Glazewski Environmental Law 207.

50 See the long title of the DFA and Kidd Environmental Law 159.

51 The Act also provides that competent local government bodies may set land development objectives for the area in question (s 27 of the DFA). The subject matter of the land development objectives includes the sustained utilisation of the environment and the optimum utilisation of natural resources (s 28(1)(b)(ii) and (viii) of the DFA). 
Provision is furthermore made in Regulations to the Act for initial environmental evaluations prepared in accordance with the integrated environmental management guidelines and if necessary, comprehensive environmental impact reports. ${ }^{52}$ It is agreed with Kidd who indicates that the inclusion of environmental considerations within the general overarching principles and procedural details of the DFA is welcomed. ${ }^{53}$ He points however to a possible cause for concern in that the actual consideration of environmental factors in the development process is left to the discretion of officials. Since the primary aim of the DFA is to expedite land development procedures, it may be that the preparation of environmental impact reports or similar consideration of the environment is seen as cause for delay in the procedure, and hence as unnecessary. ${ }^{54}$ The DFA's decision-making and conflict resolution principles also refer to environmental considerations in that among the experts who have to participate in such decisions are experts in environmental management (section 4(2)(b)).

Regardless of the fact that it was enacted prior to the 1996 Constitution and the adoption of section 24, the DFA is not empty with regard to the environment and provision for some of the requirements in terms of environmental law. However, since the DFA applies to, but is not the central law in land restitution, it may fail to secure the incorporation of environmental governance. It is however proposed that the DFA, when integrated with the application of the RLRA, may to some extent contribute to a coalescence of the objectives of section 25(7) and section 24 of the Constitution.

52 GN R1412 of 1996. See Reg 27(2) and for a further discussion, Kidd Environmental Law 160.

53 Kidd Environmental Law 160.

54 It is interesting to note that already in 1997, Kidd Environmental Law 160 articulated the hope that the implementation of the DFA, "does not sacrifice environmental sustainability on the altar of short-term expediency, since this is clearly not what the drafters of the Act intended". 


\subsection{The Restitution of Land Rights Act 22 of 1994}

While the 1993 and 1996 Constitutions established the right to restitution of land, the details of the claim procedure are set out in the RLRA. The RLRA aims at: the restitution of rights in land to persons or communities dispossessed of such rights after 19 June 1913 in terms of past racially discriminatory laws or practices; the establishment of the CRLR; and providing for all connected matters. ${ }^{55}$ The RLRA essentially provides for the administrative process to get land registered in the names of people that qualify in terms of the Act and section 24(7) of the Constitution. The key provisions of, institutions for and the processes arising from the RLRA involve the nature of the right claimed; the process for lodging a claim; the Land Claims Court (LCC); ${ }^{56}$ the Commission on the Restitution of Land Rights (CRLR); ${ }^{57}$ the options for restitution; administrative settlement procedures; ${ }^{58}$ the status of the land as the subject of a claim; and the role of the DLA.

55 See the Preamble to the Act. Some of the key role-players in the realisation of the objectives of the RLRA have been identified as: any person who has lodged a claim; the Commission on Land Restitution established under s 4; communities or groups of persons whose rights in land are derived from shared land use rules determining their common access to their land held in common; the Land Claims Court established under s 22; the High Court referred to in $\mathrm{s} 166$ of the Constitution; the Minister of Land Affairs and authorised officials from the DLA; an organ of state defined in s 239 of the Constitution and any community or member of that community. This may however not be regarded as an exclusive list of role-players. See also Scheepers Practical Guide 70.

56 In terms of the RLRA, the LCC is charged with the duty to decide on the validity of claims and to award appropriate remedies. It has the power to determine the right to restitution of any right in land, to determine or approve the compensation payable when the land of a private person is expropriated, and to determine the person entitled to the right in land. The LCC is allowed to make several kinds of orders. Since the LCC deals with the procedure and finalisation of the claim itself, this instrument may not necessarily provide the forum for environmental governance and environmental principles to be considered in land restitution or post-settlement issues.

57 In terms of $s 4$ of the RLRA, the CRLR is established to administer the process of restitution. For practical purposes, various regional Commissioners are appointed to receive and investigate claims. The CRLR attempted to review all claims lodged for purposes of validation before the end of 2002 - this date has however recently been extended to the end of 2007 and it is foreseen by some that "at the present rate and given the complexity of the claims that remain, at least a decade or two would probably be required to settle all the claims". De Villiers Land Reform: Issues and Challenges 56. The CRLR is not only responsible for the administration of claims, but also for assisting claimants in preparing their case and, where necessary, for assisting with research in doing so. The Commissioners may furthermore prioritise claims and settle claims by allowing parties in several ways to negotiate it. This includes a process of mediation. Since the CRLR is a state body established with the purpose of assisting in pre-claim and claim settlement procedures that deals with the validity and history of claims, it may also not be 
It may be argued that the RLRA simply enables an administrative process and that it is therefore not necessary for the Act to make reference to environmental matters or to incorporate any environmental law aspects. This viewpoint is contested in this article. Although the RLRA was enacted ahead of the finalisation of the 1996 Constitution, the RLRA remains the key law to regulate land restitution from the beginning to the end of the process. Pre-settlement arrangements and post-settlement support (by lack of evidence to the contrary) are mandates of the DLA either in terms of or as a result of the provisions of the RLRA. It is agreed that it is not the aim or task of exclusively the RLRA to see to land and land-use activities (or the sustainability thereof), that take place in pursuance of a settlement. It is however argued that, in order for land restitution to be sustainable and conducive to environmental protection, the RLRA must at least provide for a feasibility study or the meeting of minimum environmental requirements before a land claim process commences. This is reinforced by one of the core environmental principles contained in the NEMA, namely the precautionary principle.

Section 33 of the RLRA provides for "factors to be taken into account" by the LCC. This section states that "in considering its decision in any particular matter, the Court shall have regard to a list of aspects that, inter alia, include: the requirements of equity and justice and, if restoration of a right in land is claimed, the feasibility of such restoration and the desirability of avoiding major

the suitable forum to establish and maintain environmental governance efforts and the inclusion of environmental principles in restitution of land.

58 The RLRA makes provision also for the settlement of claims through administrative procedures instead of a legal process with the LCC and the CRLR involved. Decentralisation of powers to the Minister, Director General and regional land claims Commissioners is therefore allowed in the case of settlement of uncontroversial land claims. De Villiers indicates that this process "was given further momentum" by the appointment of Minister Thoko Didiza in 1999, who expanded administrative decisionmaking in cases where an agreement is possible. De Villiers Land Reform: Issues and Challenges 59. This has led to an increase in consent settlements since the administrative process is aimed at speeding up settlements and encouraging parties to reach agreement rather than referring disputes to the litigation process. S 42C(3), 42D(1) and 42D(3) therefore allow for the Minister of Land Affairs in his/her own capacity or by delegation to the Director General of the department of a regional land claims Commissioner, to award land to a claimant, authorise payment of compensation, acquire or expropriate land, or a combination of options in the settlement of a claim. 
social disruption. Section 33 does not make explicit reference to the taking into account of environmental disruption, environmental governance or environmental principles as a "factor to be taken into account". It is suggested that the extension of this section may be used to incorporate environmental matters in the RLRA. Section 40 of the RLRA states that the Minister may make regulations regarding (a) any matter required or permitted to be prescribed in terms of the RLRA and (b) generally, all matters which in his or her opinion are necessary or expedient to be prescribed in order to achieve the objects of the RLRA. It is recommended that section 40 of the RLRA which in general provides for the Minister to make regulations, could also be used for inclusion of matters related to section 24 of the Constitution, environmental governance and/or environmental principles. Although environmental protection is not a key objective of the RLRA, the White Paper states that environmental sustainability is of the utmost importance for the success of land reform whilst the constitutional property clause makes provision for "equitable access to all South Africa's natural resources" (section 25(4)(a)). Since the RLRA is key to land reform policy in South Africa and for the process of land restitution, it may be reasonable to expect of the Act to provide for the administration of matters that could contribute to environmental sustainability and equitable access of future generations to natural resources. Such matters may be developed, inter alia, from section 24, the definitions for environmental governance and environmental principles as discussed below.

\subsection{The role of the Department of Land Affairs}

The role of the DLA is briefly discussed as part of the institutional framework for land restitution in South Africa, and in order to contribute to a discussion on cooperative governance in land restitution. According to the DLA Strategic Plan 2005-2010, the department has a vision of an equitable and sustainable land dispensation that promotes social and economic development. Its mission is to provide access to land and to extend rights in land, with particular emphasis on 
the previously disadvantaged communities, within a well-planned environment. $^{59}$ In terms of the White Paper, at national level, the DLA is responsible for: the formulation of policies that will ensure redistribution of land, tenure reform, restitution of land, and land development; the setting of national norms and standards with regard to land matters; the management of national restitution, tenure reform and redistribution programmes; procurement of funds and allocation of budgets; the coordination of inter-governmental relations in land delivery; advising and assisting provincial DLA offices with negotiation and the administration of agency agreements, partnership arrangements, and powers delegated to other tiers of government; advising and assisting provincial offices in the implementation of programmes and projects; negotiating the settlement of restitution claims on behalf of the state; and managing a national monitoring and evaluation programme.

The DLA evidently has multiple roles to play in that, amongst other responsibilities, it has to: support the land claims process by assisting claimants in having their title to land restored and rendering support to the LCC; liaise with all affected government departments to solicit their views as to the legality and feasibility of the claim and the utilisation of the particular land; assist provincial offices in the implementation of programmes and projects; and manage a national monitoring and evaluation programme. The Strategic Plan points towards functions of the DLA in land restitution that was not expressly included in the RLRA. This phenomenon may serve to support the assumption that, as land restitution has progressed since the enactment of the RLRA, some lacunae and additional needs that were not initially foreseen (such as a need for environmental governance and the inclusion of environmental principles) have been identified.

Some confusion exists about the roles of the DLA and the CRLR, the DLA as respondent to claims and the delegation of powers by the Minister of the DLA to regional Commissioners. This article concurs with the view that the clarification 
of the roles of all bodies involved is particularly important in the pre-settlement phases as well as in the preparation for post-restitution issues that may arise from the implementation of a settlement. ${ }^{60}$ Criticism has for example been expressed that neither the DLA, nor the CRLR takes sufficient account of postsettlement issues when negotiating settlements. ${ }^{61}$ Related to this issue may be uncertainty about the role of the DLA and the question when the DLA's role in the process of restitution ends. To what extent is the DLA responsible for assisting with, coordinating and even overseeing post-settlement problems, and when do line-function departments such as the Department of Agriculture and other spheres of government, such as local governments, take over from the DLA? May the DLA be seen merely to have a monitoring function with local governments having an implementation function as soon as people have been settled on reclaimed land? These questions are important for the concerns raised in this article since the answers thereto may indicate which line functionary or sphere of government should ultimately be liable for environmental governance in land restitution - especially post-settlement endeavours.

The issue of institutional arrangements to support land restitution beneficiaries once land has been transferred, is currently receiving the DLA's attention. ${ }^{62}$ The DLA plans to develop a comprehensive strategy on what type of institutions would be appropriate to provide continuous support as well as what government intervention strategies would be appropriate if it becomes clear that some of the projects are heading for collapse. One of the proposals considered by the DLA is a pro-active land acquisition strategy. The former is a laudable development by the DLA and it is hoped that such an "acquisition strategy" will also require of the institutions to take into account environmental governance in performing their supportive functions.

60 See the view of De Villiers Land Reform: Issues and Challenges 61.

61 De Villiers Land Reform: Issues and Challenges 61

62 DLA http://land.pwv.gov.za/ 13 Apr. 


\section{Suggested environmental initiatives for the restitution of land}

Where the settlement of land restitution beneficiaries takes place irrespective of environmental governance and environmental principles, the environmental human right of current as well as future generations may be at stake. The reason for this is that not only land, but also biodiversity, soil, minerals, water, vegetation and other natural resources are involved when land is assigned to beneficiaries. As soon as a land claim is finalised, newly settled individuals and communities usually want to develop the acquired land, whether it be for agricultural, small business or tourism-related purposes. It is argued that for the results of restitution to be sustainable, some environmental aspects may be key to the process. Environmental governance and the inclusion of environmental principles, plans and programmes (incorporation of environmental policy) may not be excluded. Not only from the actual restitution of land, but also presettlement studies and post-settlement assistance. It is argued that it is of the utmost importance that government employs environmental principles in the spirit of environmental governance especially in determining the feasibility of a land claim. When restitution takes place in an environmental blind way, there is not much that government can do afterwards to rectify problematic situations. ${ }^{63}$

In terms of the White Paper, any programme that allows people more control over their lives and their environment should serve to reduce the risk of land degradation. ${ }^{64}$ One of the challenges of land reform is to relieve land pressure

63 Land restitution involves vast hectares of land. Of concern is, eg the fact that large areas of land (especially in Kwazulu-Natal and the Easter Cape provinces) are prone to overgrazing and consequent vegetation degradation which leads to significant reduction of ground cover, bush desertification, a change in species composition and a reduction of grazing capacity. Although there is a lack of data on the extent and rate of land degradation, there is sufficient evidence to indicate that South African soils are deteriorating rapidly due to poor management practice and inadequate monitoring and enforcement. There is a severe risk of increased environmental degradation if preventive and improved resource management measures do not accompany the land reform programme and land development in general.

64 The worst environmental health conditions and natural resource degradation occurs around informal settlements, where people have few assets and minimal control over their surroundings. The objectives of the land reform programme, aimed as they are at the alleviation of poverty, should ameliorate the current levels of environmental destruction associated with the crowding of large numbers of poor people on marginal, erodible and often dangerous land. 
without extending environmental degradation over a wider area. Unless projects are properly planned and the necessary measures are put in place to govern the zoning, planning and ultimate use of the land in an environmental friendly way, the programme could, inter alia, result in land being used unsustainably, or scarce, good quality arable land could be converted to residential uses. Furthermore, in providing post-settlement support, it may be of key importance to inform and capacitate land claim beneficiaries as well as the relevant officials and line functionaries of government. The conducting of environmental impact assessments for activities on land or change of land use and permit and licensing requirements in terms of environmental legislation should not be foreign notions to those involved in, or benefiting from land restitution.

Without providing an exclusive list, subsequent paragraphs put forward some public law and environmental law aspects proposed as some basic initiatives for land restitution in the aim to allow for sections 24 and 25(7) of the Constitution, to merge in practice.

\subsection{A move towards co-operative governance}

South Africa's land restitution process is characterised by a high degree of segmentation as a result of which all of the relevant departments are not always involved from the early stages to the implementation of land claims outcomes. $^{65}$ In many instances local governments and/or provincial departments are involved only very late in the resettlement phase, or even worse, only at the implementation stage.

65 Based on research conducted in the North-West Province, Mbao 2002 Journal for Juridical Science 112 indicates that there is a lack of synergy between the restitution process and socio-economic development needs of successful claimants, including problems resulting from poor co-ordination between the various governmental agencies involved with issues of reconstruction and development at national and provincial levels. He furthermore indicates that there are organisational constraints within associated government departments, including lack of co-ordination across sectors and at different levels, and the fragmented ownership and control of public land. 
This is too late as it affects their ability to take co-ownership of the process and also ignores the contribution they could make in developing post-settlement support schemes. ${ }^{66}$

This situation may arise from the fact that the legislation lacks clear mandates for specific spheres or functionaries of government, resulting in uncertainty as to who is meant to do what and how.

This article suggests that co-operative governance by departments and institutions of government, and sound working arrangements between its national, provincial and local spheres, are fundamental if land restitution is to deliver sustainable results. The achievement of both quantitative and qualitative restitution results that contribute to sustainable development requires an intricate combination of socio-economic factors. It can therefore not be achieved single-handedly and requires the involvement of all the relevant roleplayers. ${ }^{67}$

The execution of the distinct governmental functions should be based on the constitutionally entrenched principle of co-operative governance as embedded in sections $41(1)(e)-41(1)(h)$ of the Constitution. ${ }^{68}$ This may also hold true for the distinct governmental functions required for sustainable land restitution. For the purpose of this article, particular emphasis may be placed on the sections stipulating that all spheres of government and all organs of state within each sphere must: respect the constitutional status, institutions, powers and functions of government in other spheres (section 41(1)(e)); exercise their powers and perform their functions in a manner that does not encroach on the geographical, functional or institutional integrity of government in another sphere (section 41(1)(g)); co-operate with one another in mutual respect and good faith by assisting and supporting one another (section 41(1)(h)(ii)); and

66 De Villiers Land Reform: Issues and Challenges 84.

67 These role-players include for example provincial and local government structures, municipalities and district councils. According to a 2003 Report of the office of the Chief Land Claims Commission, "it has become abundantly clear that there is a need to include restitution in the municipal IDP's with the view to achieve the synergistic results of cooperative governance", n 38 above CRLR http://land.pwv.gov.za/restitution 13 Apr.

68 Bosman, Kotzé and Du Plessis 2004 SA Public Law 412. 
co-ordinating their actions and legislation with each other (section 41(1)(h)(iv)). Each department and sphere of government hence exists as a distinctive body with its own unique character, but functions on the basis of interdependence and interrelation with others.

The provisions of chapter 3 of the Constitution are not meant to diminish the power of one organ of state at the expense of another. Rather they presuppose and emphasise the willingness of all spheres and functionaries of government to work together. As far as the realisation of sections 24 and 25(7) of the Constitution is concerned, this may mean that for example the DEAT, the DLA and the DPLG with the supportive assistance of national, provincial and local government, should govern land restitution in an interdependent and interrelated way. This may require mutual support, so that conflict between land restitution law and environmental law is avoided, and so that administration and implementation of these laws are clearly regulated by way of co-ordination. ${ }^{69}$

To ignore government's inter-supportive obligation is to render the provisions on co-operative governance null, void and futile - therefore, "mutual support and co-operation are imperative to create consulted, public participatory, open, administratively just, democratic and accountable governance; which principles should form the backbone of constitutional values underlying society as a whole". ${ }^{70}$ Accordingly, the DLA may be applauded for stating in its Strategic Plan that "addressing the challenge of integrated planning has become a priority for government". ${ }^{71}$ The Strategic Plan states that the DLA and the CRLR will in future be collaborating with a number of sister departments on different projects and programmes. ${ }^{72}$ It is hoped that these "sister departments" will not only include the DEAT, but also the spheres of government responsible for and capacitated to see to environmental affairs.

69 See De Waal, Currie and Erasmus The Bill of Rights Handbook 24; and Bosman, Kotzé and Du Plessis 2004 SA Public Law 413.

70 Bosman, Kotzé and Du Plessis 2004 SA Public Law 414 and s 1 of the Constitution.

71 DLA http://land.pwv.gov.za/ 13 Apr.

72 A monitoring and evaluation system that can track progress with implementation of land policy and environmental conservation measures that can provide timeouts feedback to managers and the public, may furthermore be key elements in ensuring that policy measures are able to achieve their intended goals. 


\subsection{The clarification of roles and elucidation of functions}

According to the White Paper, the existing public land management system lacks a coherent information system and is characterised by a lack of clarity with regard to the roles, responsibilities and policies of the different institutions involved. This arguably holds true not only for the land management system itself, but also for the separate land reform programmes, such as land restitution. Analogous hereto, the administration of environmental matters in South Africa is still problematic regardless of modern environmental

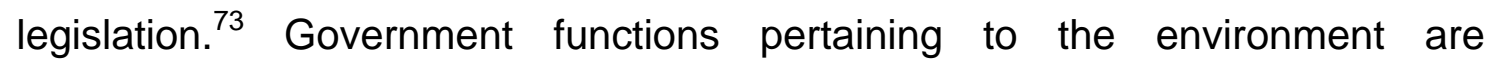
sometimes exercised simultaneously by various organs of state and spheres of government. ${ }^{74}$ It therefore seems as if the different roles of government in preand post-land restitution activities, with specific reference to the inclusion of environmental concerns, require improved definition and clarification. ${ }^{75}$ It may be of no use to ask for co-operative governance and environmental governance in land restitution when it is not clear who are mandated and capacitated to assist, when and where.

There is no coherent or sufficient national land use policy that could guide the actions of specific departments or spheres of government in dealing with problems experienced by new landowners. ${ }^{76}$ During the claim phase of land

73 Bosman, Kotzé and Du Plessis 2004 SA Public Law 411. See also Snyman "Co-operative Governance" 295.

74 Bosman, Kotzé and Du Plessis 2004 SA Public Law 412. Ch 3 of the Constitution, in this regard, also provide for national, provincial and local spheres of government to perform varying functions unique to the specific sphere of government. In this sense "governance" may be described as "... both the process and structure by which officials are held accountable for executing the fiduciary duty with which they are entrusted to the public". See Turton's definition in Bosman, Kotzé and Du Plessis 2004 SA Public Law 412.

75 It is essential to define clearly what the role of the respective government departments and even non-governmental organisations such as farmer's unions are and at what stage they should become involved in land restitution policy development and implementation. It is suggested that consideration is given to the establishment of an intergovernmental committee on land reform in each province, where all national, provincial and local governments with an interest in land reform could be brought together to oversee the process, make adjustments and consider post-settlement support. De Villiers Land Reform: Issues and Challenges 81-87.

76 De Villiers 2000 (4) SA Public Law 438 indicates that this is not a factor unique to South Africa but that also in Australia "there is no clarity on the type of support to be offered to aboriginal people once native title has been determined in their favour". 
restitution, the DLA initially directed the process in a very centralised manner to the virtual exclusion of other national and provincial government departments. The DLA had an exclusive claim settlement style and paid little, if any, attention to the development of a land management policy that would follow restitution. ${ }^{77}$ In recent years the DLA has however shown greater awareness in involving other national and provincial departments and local authorities in the preacquisition process. However, there is still no integrated and coherent strategy whereby the role and functions of the respective departments are spelled out at national level. ${ }^{78}$ Hence, it remains unclear who takes responsibility to make the land policy "work" and who takes ownership of the process before settlement takes place and once land has been acquired. ${ }^{79}$ Similarly, it is not clear who may be held accountable to ensure or co-ordinate environmental governance of a land claim. ${ }^{80}$

Of further concern is the fact that the DLA is not positioned to oversee implementation but at the same time no other department has been instructed to oversee or to coordinate the process. The skills required to assist in the settlement of new landowners are in many instances not found in a single government department as the needs of resettled people may span various

77 In this regard reference can be made to the disappointment that arose in areas such as Riemvasmaak, Elandskloof and Doornkop where the return to land was celebrated with great fanfare but was soon forgotten in the rush as the DLA headed off to settle the next claim. De Villiers Land Reform: Issues and Challenges 69.

78 De Villiers Land Reform: Issues and Challenges 69.

79 In terms of the Constitution, deeds registration, land survey and land reform, including land restitution, are the responsibility of national government. Provincial governments, however, also have responsibility in a number of functional areas that are closely related to land reform. These are mainly areas where national and provincial governments have concurrent responsibility in terms of Schedule 4 of the Constitution and include amongst others, environment, soil conservation and urban and rural development. Traditional authorities also carry out land-related functions in terms of customary law. All three spheres of government and traditional authorities accordingly have functions that require land administration. However, at present most of the legislation dealing with land administration has been assigned to the Minister of the DLA.

80 Note that the service delivery improvement programme of the DLA, which indicates some of the specific services of the DLA, currently does not contain a single service related to, or alluding to, environmental governance or environmental principles. Similarly no provision is made for the bringing on board of a line functionary or specific sphere of government to assist in environmental related services or matters. See the DLA http://land.pwv.gov.za/ 13 Apr. 
departments such as DLA, DEAT and the Department of Education and different spheres of government. ${ }^{81}$

In aiming to make section 24 and 25(7) of the Constitution work in a mutually supportive way, the departments and spheres of government involved have to operate in a co-ordinated fashion. This may, however, only be possible where the roles of concerned state bodies are clearly and realistically defined and documented. It is proposed that once the roles of involved parties become unambiguously clear, it may be possible to utilise environmental and land restitution policy in a systematic and integrated fashion.

\subsection{Integrated compliance with environmental- and land restitution law}

Property rights and environmental rights as protected by the Constitution "appear to compete" - the right to property is a private law right while the environmental clause protects private and public interests. ${ }^{82}$ The right to property furthermore aims to address imbalances inherited from the past, whilst the environmental clause aims to protect the environment of the present generation, and generations yet to be born. It is suggested that in order for sections 24 and 25(7) not to counteract each other in an antagonistic way, legislation that has been developed in terms of, or in order to realise these rights should be complied with in an integrated fashion. This may require a difficult balancing act where objectives in environmental law and land restitution seem to be in conflict. It is suggested that in such circumstances, the aims of national development in general, the people and area involved, alternatives in

81 Although efforts are made to involve local governments more effectively in land restitution, many local governments suffer serious capacity and financial problems - especially in rural areas. A lack of capacity and money may be the defence not only of local governments, but also of government departments currently not actively involved in land restitution and the pre- and post- settlement phases thereof. It is however proposed that especially in the light of $s$ 24(b) (that provides for the protection of the environment for present and future generations), and with land restitution to be completed in the next two years, government should consider the revisiting of capacity-building endeavours and budgets.

82 Glazewski Environmental Law 83 
land restitution and environmental protection as well as the possible application of the constitutional limitation clause ${ }^{83}$ should be carefully considered.

Since 1994, the DLA and the CRLR were concerned with laying the foundation for the implementation of land and agrarian reform as well as land planning and information. This meant that the policy and legislative framework had to be set in place for all the aspects of land reform, together with systems and procedures being developed to enhance implementation. Some of the most significant pieces of legislation that the DLA passed during that time were, amongst others; the RLRA, the DFA, the Land Reform (Labour Tenants) Act, 1996, the Extension of Security and Tenure Act, 1997, the Planning Profession Act, 2003 and the Communal Land Rights Act, 2004. Almost concurrently, environmental law in South Africa was revitalized and strengthened by, inter alia, the enactment of the NEMA and the development of EIA regulations in terms of the ECA.

The DLA is currently fast-tracking land law implementation and has begun the process of undertaking a comprehensive review of all of its policies to determine if they are still relevant or whether the time for innovation has arrived. ${ }^{84}$ This process will include the revision of land restitution law. As part of the policy review process, consultation with relevant stakeholders had already begun. ${ }^{85}$ A national Land Summit took place in July 2005. It was expected of the Land Summit to become a forum for discussion and commentary on the inclusion of several aspects in the process of land reform in general, but also specifically for discussion and commentary on the inclusion of environmental issues in the restitution of land. Unfortunately politics and matters such as problems with the "willing buyer, willing seller"-approach dominated the agenda. A determination of the way in which environmental policy may be utilised to support and strengthen the ultimate aims of land restitution policy, however, remains vital for the future performance of the DLA.

$83 \mathrm{~S} 36$ of the Constitution.

84 DLA http://land.pwv.gov.za/ 13 Apr.

85 It will be interesting to see whether the DEAT is recognised by the DLA and whether it sees itself, as "relevant stakeholder" to partake in these consultations. 


\subsection{The employment of environmental impact assessment and the environmental principles}

When land is returned in terms of the land restitution programme, this has implications not only for the people involved, but also for the environment. This impact does not have to be contra-section 24 of the Constitution. In terms of existing environmental law as discussed above, it is possible to utilise, inter alia, environmental impact assessments and environmental principles to minimise negative impacts.

It is accordingly suggested that the "administrative or regulatory process by which the environmental impact of the project is determined", may be of cardinal importance for land restitution. ${ }^{86}$ Environmental impact assessments are required in terms of the ECA and should be conducted for any listed activity that may be part of pre-settlement, restitution or post-settlement support endeavours on land. ${ }^{87}$ It is furthermore proposed that in line with co-operative governance, the DEAT should pay special attention to and monitor environmental impact reports that describe the process of examining environmental affects of development that follows land restitution, the expected impacts and the proposed mitigating measures.

Apart from the conducting of environmental impact assessments, it is also proposed that state departments, spheres of government, government officials and land restitution beneficiaries involved in land restitution should understand and operate by the environmental principles as captured in section 2 of the NEMA. Section 2(1) determines that the principles set out therein "apply throughout the Republic to the actions of all organs of state that may significantly affect the environment and shall apply alongside all other appropriate and relevant considerations, including the State's responsibility to

86 Fuggle and Rabie Environmental Management 764. See for different definitions of environmental impact assessments, Glazewski Environmental Law 231.

87 See s 21 and 23, Part 5 and the regulations to the Act. 
respect, protect, promote and fulfil the social and economic rights in Chapter 2 of the Constitution and in particular the basic needs of categories of persons disadvantaged by unfair discrimination" (section 2(1) of the NEMA). Furthermore it is determined that: development must be socially, environmentally and economically sustainable; that the disturbance of ecosystems and loss of biological diversity are avoided, or, where they cannot be altogether avoided, are minimised and remedied; that pollution and degradation of the environment are avoided, or, where they cannot be altogether avoided, are minimised and remedied; that a risk-averse and cautious approach is applied, which takes into account the limits of current knowledge about the consequences of decisions and actions; that negative impacts on the environment and on people's environmental rights be anticipated and prevented, and where they cannot be altogether prevented, are minimised and remedied; that decisions must take into account the interests, needs and values of all interested and affected parties; that the social, economic and environmental impacts of activities, including disadvantages and benefits, must be considered, assessed and evaluated, and decisions must be appropriate in the light of such consideration and assessment; and that there must be intergovernmental co-ordination and harmonisation of policies, legislation and actions relating to the environment.

This article suggests that if the current steps and processes that are part of land restitution are revisited and aligned to accommodate the former key environmental principles as framework guidelines for restitution, it may be unlikely for section 25(7) to debilitate the rights of present and future generations as contained in section 24 of the Constitution.

\subsection{The timely assimilation of environmental governance and -support}

An inherent risk with regard to land reform law as it exists lies in the fact that the law does not explicitly provide for measures that will ensure benefits in land 
for the next generation. ${ }^{88}$ In some instances the return of people to land without the necessary environmental governance and support system in place may create more long-term problems than it solves. ${ }^{89}$ The risk is that issues and grievances related, for example, to section 24 may be building up and that the next generation may want to revisit questions that the current generation thought had been adequately dealt with. The restitution of lost land rights itself offers no assurance with regard to livelihoods. Hence environmental governance, as defined earlier in this article ${ }^{90}$ and support are of great importance. ${ }^{91}$ It is argued that environmental governance and support should be applied already in pre-settlement investigations.

It should be noted that, according to the White Paper, prior to disbursing the Settlement/Land Acquisition Grant, the Department requires that grant applicants, with the assistance of planners, prepare a feasibility study which among other aspects includes an assessment of the environmental consequences of the proposed undertaking. This requires the applicants to consider the suitability of the natural resources for the proposed production system, and the environmental impact of the proposed residential development. The Settlement/Land Acquisition Grant with its prerequisites is however only available once a land claim has already been settled. Since the grant process follows after a claim, it may only provide limited protection in the form of environmental assessment and can therefore not be offered by government as sufficient proof of the inclusion of environmental governance in land restitution endeavors.

In its Strategic Plan the DLA states that, in order to achieve sustainable development and livelihoods through the land reform process, environmental guidelines for effective land reform have been put in place:

88 De Villiers Land Reform: Issues and Challenges 70.

89 Without explicit reference to the environment, but with regard to socio-economic conditions in general, Mostert 2002 The South African Law Journal 427-428 indicates that postsettlement support is of the "utmost importance".

90 See par 2 above.

91 De Villiers Land Reform: Issues and Challenges 70. 
This year a substantial amount of the required resources are in place and full roll-out is anticipated. ${ }^{92}$

What these environmental guidelines are remains uncertain and how "effective land reform" is or will be determined is unclear. As far as could be established, no environmental guidelines for land restitution have been established in terms of restitution policy or law. ${ }^{93}$ This is an alarming state of affairs that may, however, be reversed by means of co-operative governance, the clarification of roles and the integrated application of environmental and land restitution law as discussed above.

\section{$5 \quad$ Related issues distilled from the Khomani San case}

In 1999 the Khomani San community successfully reclaimed large areas of land in the Andriesvale-Askam area of the Kalahari, in terms of the RLRA. The claimant group received six farms totalling approximately 40000 hectares of land. In 2004 it came to the attention of the South African Human Rights Commission (hereafter the SAHRC), through media reports and complaints from the community, that five years after the successful land claim the Khomani San continue to live in abject conditions, without full enjoyment of their human rights. An Inquiry was launched in 2004 that consisted of three phases: research, consultation and a public hearing. The Inquiry addressed a complex and intertwined set of challenges around relationships, co-operative governance, just administrative action, capacity-building and sustainable development. $^{94}$

The purpose of the Inquiry was not to find anybody culpable in a sense of guilt or innocence, nor was it seeking to embarrass. Rather the aim was, by means of a qualitative study, to understand how human rights, such as the

92 DLA http://land.pwv.gov.za/ 13 Apr.

93 The author of this article was furthermore unable to access, or in the alternative, to determine whether the DLA has drafted environmental management plans and/or environmental implementation plans as required by the NEMA as discussed earlier.

94 See SAHRC http://www.sahrc.org.za/ 13 Apr. 
environmental human right, have been advanced, and what the challenges are to these rights being furthered in the community. The unstructured interviews, discussions and the hearing that formed part of this study, revealed several aspects that may be related to sections 24 and 25(7) of the Constitution. ${ }^{95}$ These include: that government has failed to provide water, sanitation, waste management or development in general on the restituted Khomani San land, despite funding being available for this purpose; that a local development plan which arguably should have been in place before the restitution process took place, was submitted to the CRLR only on 17 September 2004 - five years after the claim had been approved. It was furthermore observed that a need existed for clarification of the roles of different levels and departments of government, and for all spheres of government to fulfil their responsibilities in a co-ordinated manner in the land restitution process; and that a Cabinet Memorandum strategising co-operative governance for the Khomani San had been submitted to Parliament by the DPLG only in October 2004.

Several sections of the Bill of Rights were particularly pertinent with regard to the predicament of the Khomani San community. In a normative sense, these included the right to dignity, life, freedom and security of the person, the right to access to health care and services, the right to just administrative action and the right to have the environment protected. As far as development of the Khomani San people and the reclaimed land was concerned, the SAHRC decided not to rely on failed policy implementation. It was, however, evident that the RLRA and the implementation of its provisions do not make provision for the inclusion of socio-economic needs, environmental principles or environmental governance. Furthermore, the provisions of the ECA, NEMA or merely the spirit of section 24 of the Constitution have not received priority in the restitution processes of the past five years. It was also not clear which department could in actual fact be held accountable for the failure of environmental governance on 40000 hectares of land for example. This may serve to prove that even for the "watch dog" government institutions (institutions

95 For a comprehensive outline of the research methods used in this qualitative study, see the SAHRC http://www.sahrc.org.za/ 13 Apr. 
in terms of chapter 9 of the Constitution), it is unclear who should be held responsible for what aspects of governance in general, but also specifically environmental governance. One of the key recouping recommendations of the SAHRC was that two external managers (a farm manager and a general executive manager) with the DLA as overseer, be appointed to assist the Khomani San community to manage and cultivate land, and to understand the rights, assets and obligations afforded to the community by the land claim.

This case study serves to prove that the environmental initiatives for land restitution discussed in this article, have been critical since the settlement of the very first land claim in South Africa. At the time of this settlement, the DLA was not yet driven by time since the cumbersome pace of the land claims process had not been foreseen. Bearing in mind that the international eyes have been on the government's resettlement of the "first people of Africa", the Khomani San, government had even more reason to see to the flawless settlement of this community. The current pressure on government to speed up the finalisation of the remaining land claims and the possible seclusion of environmental concerns is therefore a cause of concern to be taken up very seriously.

\section{Conclusion}

The land restitution process in South Africa is unique in scale and complexity. ${ }^{96}$ Land restitution is nevertheless crucial for sustainable development and democratic change. ${ }^{97}$ Government furthermore has obligations and duties in terms of sections 24 and 25 of the Constitution (within the framework of the chapter 2 Bill of Rights) to improve the socio-economic conditions of existing and future generations. ${ }^{98}$ It is argued in this article that in the process of

96 De Villiers Land Reform: Issues and Challenges 87.

97 This statement is in support of Mostert's viewpoint that "restitution must be conducive to the process of reconciliation, reconstruction and development". See Mostert 2002 Journal of South African Law 167.

98 This strongly links with the increased emphasis in research on government's role and obligations with regard to social and environmental justice. 
addressing some of the land-related ills that emanated from South Africa's political history and in the move towards sustainable development, the constitutional provision for land restitution should be married with the constitutional protection afforded to people's environmental rights.

This article aimed to determine whether environmental- and co-operative governance are present in the existing legal framework for land restitution, whether land restitution- and environmental law is complied with in an integrated fashion, whether the phases of land restitution provide in practice for environmental matters, and whether or not government's increasingly rapid implementation of section 25(7) could impede some of the objectives of section 24. A critical overview of the legal framework on environmental governance and the legislative and institutional framework for land restitution in South Africa, in the most uncomplicated way, showed the answer to the first three questions to be no. Therefore, rather obviously, it is possible to infer that the increasingly rapid finalisation of land claims may impede some of the objectives of the environmental human right entrenched in section $24 .{ }^{99}$

In paragraph 4 of this article it was aimed to highlight some public law and environmental aspects and basic initiatives for land restitution that may be used by government in remaining land restitution endeavours. Following the overview of the legal frameworks concerned it was suggested that in the process of restituting land in terms of section 25(7) and other land restitution law, environmental harm or damage may be prevented or remedied with a deliberate move by government towards co-operative governance, with an effort to clarify the roles and functions of government departments and spheres involved in land restitution matters, with an effort to comply with environmental- and land restitution law in an integrated fashion, with the employment of environmental impact assessments and environmental

99 Note that currently a number of problems of a socio-economic nature, accompany government's settling of land claims. This article, however, primarily focused on the protection of the environmental human right in land restitution practices and different problems or challenges that are related. This strongly links with the increased emphasis in research on government's role and obligations with regard to social and environmental justice. 
principles and with the timely assimilation of environmental governance and support in land restitution practices.

The particular public law and environmental aspects and basic initiatives were distilled from existing strategies and approaches to be found in related literature. They are regarded as most relevant to address the environmental concerns related to land restitution that were identified as part of the analysis of the legislation concerned, the current modus operandi of the DLA and the facts of the Khomani San case. Some of the concerns raised in this article entail that:

- land restitution in general requires a long-term vision that is sustainable as, in its absence, socio-democratic change and development in South Africa (as one of the ultimate aims of the Constitution) may become at stake;

- although land restitution is in essence an administrative process in terms of the RLRA, and although government is currently subject to relentless critique in this regard, the impacts of land restitution on the environment have to be assessed and governed in the processes that precede and follow settlement. When restitution takes place in an environmentally blind way, there is not much that government can do afterwards when it is revealed that for example the soil or vegetation in a specific area, is not susceptible to development;

- it remains unclear who takes responsibility to make the land policy "work" as well as who takes ownership of the process before settlement takes place or once land has been acquired. Similarly, it is not clear who may be held accountable to ensure or co-ordinate environmental governance of a land claim. Of concern is the fact that the DLA is not positioned to oversee implementation but at the same time no other department has been instructed in terms of law to oversee or to coordinate the process. The skills required to assist in the settlement of new landowners are in many instances not found in a single government department as the needs of people may span various departments. Whilst the DLA, the DEAT and the DPLG have 
been referred to in this article, national government has to investigate the roles of each state body and sphere of government with regard to the socio-economic issues involved in land restitution. This article calls for particular emphasis on secured ecologically sustainable development, pollution control and conservation;

- land restitution and environmental law as it exists should be complied with simultaneously and where a conflict arises, development could be used as a yardstick for preferential application; and

- environmental awareness-raising, the conducting of environmental impact assessments and the application and monitoring of environmental principles in the processes that precede and follow land settlement, are key aspects that should accompany land restitution despite the need to speed up this process. Some of the detrimental effects where environmental law and environmental principles have previously not been employed in land restitution were hinted to in the Khomani San case discussed in paragraph 5.

Two and a half years remain for government in which to reconsider and revisit its approach to land restitution and the environmental impact thereof. The fasttracking of the land restitution process in practice requires increased consideration of the matters that may be left behind. It may be fatal for the sake of sustainable development to focus on the assumed political benefits and mere property redress without considering the impact on the environment of the thousands of people involved. 


\section{Bibliography}

Badenhorst et al Silberberg and Schoeman's The Law of Property Badenhorst PJ et al Silberberg and Schoeman's The Law of Property $4^{\text {th }}$ ed (Butterworths Durban 2003)

Bosman Waste Disposal or Discharge 8-12

Bosman C Waste Disposal or Discharge: A Harmonised Regulatory Framework Towards Sustainable Use (M Sc Environmental Management Dissertation PU for CHE 1999)

Bosman, Kotzé and Du Plessis 2004 SA Public Law

Bosman C, Kotzé LJ and Du Plessis W "The failure of the Constitution to ensure integrated environmental management from a co-operative governance perspective" 2004 (19) SA Public Law 411-421

Bray 1998 SAJELP

Bray E "Towards Sustainable Development: Are we on the right track?" 1998 South African Journal of Environmental Law and Policy 1-15

Cheadle, Davis and Haysom South African Constitutional Law Cheadle MH, Davis DM and Haysom NRL South African Constitutional Law: The Bill of Rights (Butterworths Durban 2002)

De Villiers 2000 (4) SA Public Law De Villiers B "Africa 2000 - the progress with land claims and reflections on the Australian process" 2000 (15) SA Public Law 426-438

De Villiers Land Reform: Issues and Challenges

De Villiers B Land Reform: Issues and Challenges A comparative overview of experiences in Zimbabwe, Namibia, South Africa and Australia (Occasional Paper Series of the Konrad-Adenauer-Stiftung South Africa 2003) 
De Waal, Currie and Erasmus The Bill of Rights Handbook

De Waal J, Currie I and Erasmus G The Bill of Rights Handbook $4^{\text {th }}$ ed (Juta Cape Town 2001)

Du Plessis, Olivier and Pienaar 1998 SA Public Law

Du Plessis W, Olivier N and Pienaar J "Land reform surging forward" 1998 (13) SA Public Law 470-489

Du Plessis, Olivier and Pienaar 1998 SA Public Law

Du Plessis W, Olivier N and Pienaar J "Land: still a contentious issue" 1998 (13) SA Public Law 149-169

Du Plessis, Olivier and Pienaar 1999 SA Public Law Du Plessis W, Olivier N and Pienaar J "Land reform: trends developing in case law" 1999 (14) SA Public Law 528-553

Du Plessis, Olivier and Pienaar 2000 SA Public Law

Du Plessis W, Olivier N and Pienaar J "Land reform: a never-ending process" 2000 (15) SA Public Law 230-254

Du Plessis, Olivier and Pienaar 2000 SA Public Law

Du Plessis W, Olivier N and Pienaar J "New measures to expedite land reform" 2000 (15) SA Public Law 549-573

Du Plessis, Olivier and Pienaar 2004 SA Public Law

Du Plessis W, Olivier N and Pienaar J "Land Matters: New Developments" 2004 (19) SA Public Law 456-470

Du Plessis, Olivier and Pienaar 2005 SA Public Law

Du Plessis W, Oliver N and Pienaar J "Land Matters: New Developments" 2005 SA Public Law (to be published)

Freedman 2001 SAJELP

Freedman W "Environmental Conservation and the Concept of Ownership $42 / 46$ 
as an Absolute and Unrestricted Right: Minister of Public Works and Others v Kyalami Ridge Environmental Association and Another" 2001 (8) SAJELP $128-134$

Fuggle and Rabie Environmental Management

Fuggle RF and Rabie MA Environmental Management in South Africa (Juta Cape Town 1992)

Glazewski Environmental Law

Glazewski J Environmental Law in South Africa $2^{\text {nd }}$ ed (Butterworths Durban 2005)

Kidd Environmental Law

Kidd M Environmental Law: A South African Guide (Juta Cape Town 1997)

Mbao 2002 Journal of Juridical Science

Mbao MLM "Undoing the injustices of the past: restitution of rights in land in post-apartheid South Africa with special reference to the North-West

Province" 2002 (2) Journal for Juridical Science 88-113

Mostert 2002 Journal of South African Law

Mostert H "The Case of the Richtersveld Community" 2002 (1) Journal of South African Law 160-167.

Mostert 2002 The South African Law Journal

Mostert H "Land Restitution, Social Justice and Development in South

Africa" 2002 (1) The South African Law Journal 400-428

Nel and Du Plessis 2004 SA Public Law

Nel JG and Du Plessis W "Unpacking Integrated Environmental Management: A Step Closer to Effective Co-operative Governance?" 2004 (19) 1 SA Public Law 181-190 
Rautenbach and Malherbe Staatsreg

Rautenbach IM and Malherbe EFJ Staatsreg $3^{\text {rd }}$ ed (Butterworths Durban 1999)

Scheepers Practical Guide

Scheepers T A Practical Guide to Law and Development: An Introduction to the Law Applicable to the Development Management Process in South Africa (Juta Kenwyn 2000)

Scholtz 2005 Journal of South African Law

Scholtz W "The anthropocentric approach to sustainable development in the National Environmental Management Act and the Constitution of South Africa" 2005 (1) Journal of South African Law 69-85

Snyman "Co-operative Governance" 295

Snyman E "Towards Co-operative Governance in the North West Province: Integration of Authorisation Processes" in IAIA Conference Proceedings Wildernis 1-3 September 2003

UN General Assembly Our Common Future UN General Assembly Our Common Future (Brundtland Report) Res 422118611 of Dec 1987

Van der Walt 1997 SA Public Law

Van der Walt AJ "The limits of constitutional property" SA Public Law (1997) (2) 275-330

\section{Register of legislation}

Communal Land Rights Act 2004

Constitution of the Republic of South Africa 1996

Constitution of the Republic of South Africa 200 of 1993

Development Facilitation Act 67 of 1995

Environmental Conservation Act 73 of 1989

Extension of Security and Tenure Act 1997 
GN R1412 Government Gazette 1739530 August 1996

Land Reform (Labour Tenants) Act 1996

National Environmental Management Act 107 of 1998

Planning Profession Act 2003

Restitution of Land Rights Act 22 of 1994

White Paper on South African Land Policy Department of Land Affairs 1997

\section{Register of cases}

Minister of Public Works and Others v Kyalami Ridge Environmental Association and Others 2001 (7) BCLR 652 (CC)

Silvermine Valley Coalition v Sybrand van der Spuy Boerderye and Others 2002 (1) SA 478 (CPD)

\section{Register of Internet resources}

CDE Research Report http://www.cde.org.za/pdf/LandReform.pdf 14 Apr Centre for Development and Enterprise's Research Report 2005 Land Reform in South Africa A $21^{\text {st }}$ Century Perspective [Found on Internet] http://www.cde.org.za/pdf/LandReform.pdf [Date of use 14 Apr 2006]

CRLR http://land.pwv.gov.za/restitution $13 \mathrm{Apr}$

Commission on Restitution of Land Rights 2003 Land Restitution in South Africa: our achievements and challenges [Found on Internet] http://land.pwv.gov.za/restitution [Date of use 13 Apr 2006]

DLA http://land.pwv.gov.za/ 13 Apr

Department of Land Affairs 2005 Strategic Plan 2005-2010: Sustainable Land and Agrarian Reform: A Contribution to Vision 2014 [Found on Internet] http://land.pwv.gov.za/ [Date of use 13 April 2006]

DLA http://land.pwv.gov.za/ 13 Apr

Department of Land Affairs 2004 Performance Review 2003/2004 [Found on Internet] http://land.pwv.gov.za/ [Date of use 13 April 2006] 
SAHRC http://www.sahrc.org.za/ 13 Apr

South African Human Rights Commission 2004 Inquiry Report on Human

Rights Violations against the Khomani San Community [Found on Internet]

http://www.sahrc.org.za/ [Date of use 13 April 2006]

Transformation Audit http://www.transformationaudit.org.za/ 13 Apr

Transformation Audit 2005 National Treasury, Vote 29: Land Affairs

National Estimates of Expenditure [Found on Internet]

http://www.transformationaudit.org.za/ [Date of use 13 Apr 2006] 